\title{
A high frequency time series at weathership $M$, Norwegian Sea, during the 1997 spring bloom: feeding of adult female Calanus finmarchicus
}

\author{
Xabier Irigoien ${ }^{1 *}$, Robert Head ${ }^{1}$, Ulrike Klenke ${ }^{2}$, Bettina Meyer-Harms ${ }^{1}$, \\ Derek Harbour ${ }^{1}$, Barbara Niehoff ${ }^{2}$, Hans-Jürgen Hirche ${ }^{2}$, Roger Harris ${ }^{1}$
}

\author{
1'Plymouth Marine Laboratory, Prospect Place, Plymouth, PL1 3DH, United Kingdom \\ ${ }^{2}$ Alfred Wegener Institute for Polar and Marine Research, D-27656 Bremerhaven, Germany
}

\begin{abstract}
The feeding ecology of Calanus finmarchicus was investigated during spring 1997 at a permanent station in the Norwegian Sea (Stn $\mathrm{M}, 66^{\circ} \mathrm{N}, 2^{\circ} \mathrm{E}$ ) as part of the TASC (Trans Atlantic Study of Calanus finmarchicus) project time-series investigations. The phytoplankton bloom began in mid May, coinciding with the onset of the stratification, and was mainly composed of diatoms and prymnesiophytes. Daily ingestion of phytoplankton by $C$ finmarchicus was about $2 \%$ of body carbon for the long period before the bloom, 30\% during the bloom and $14 \%$ after the bloom. Due to their low abundance, ingestion of ciliates represented only 2 to $6 \%$ of the phytoplankton ingestion. Body carbon and carbon/nitrogen ratio decreased significantly before the bloom indicating a deficit in carbon ingestion and the use of storage lipid during this period.
\end{abstract}

KEY WORDS: Calanus finmarchicus $\cdot$ Norwegian Sea $\cdot$ Feeding $\cdot$ Phytoplankton $\cdot$ Ciliates

\section{INTRODUCTION}

Calanus finmarchicus is a dominant component of North Atlantic zooplankton and is the main food of larvae of commercially important fish such as cod, haddock, capelin, herring and red-fish (Bainbridge \& McKay 1968, Ellertsen et al. 1981, Kane 1984, Astthorsson \& Gislason 1997). C. finmarchicus is likely to play an important role in the recruitment success of these species (Burd 1963, Cushing 1982, Maravelias \& Reid 1997). It has been suggested that interannual variability in climate could affect fish recruitment through links between the physical conditions, primary production and secondary production (see review in Runge 1988). Runge (1988) proposed that because of the higher sensitivity of the productivity of C. finmarchicus to food concentration, this species was most likely to form a strong link in the food chain from

·E-mail: xi@wpo.nerc.ac.uk phytoplankton to fish via copepods. This would be the case in the Calanus sp. dominated areas and Calanus feeding fish populations rather than in systems dominated by small copepods, which are less sensitive to changes in food concentration. Since the first work by Marshall (1924), feeding of the genus Calanus has been the subject of a large number of studies (see review in Harris 1996). Nevertheless, and because of obvious practical and infrastructure limitations, studies on variations of $C$. finmarchicus feeding rates in the open sea are scarce. Mechanisms controlling C. finmarchicus arousal are still not well understood (see review in Miller et al. 1991), but due to the strong influence of climatic conditions on the development of phytoplankton in the oceanic areas of the North Atlantic (Sverdrup 1953), the lapse of time between C. finmarchicus arousal and phytoplankton bloom can differ, not only between coast and open sea areas (Niehoff \& Hirche 1997) but also between different areas in the open sea. As an example, south of Iceland (Stn India, $59^{\circ} \mathrm{N}, 18^{\circ} \mathrm{W}$ ) arousal seems to coincide with 
the phytoplankton bloom with C finmarchicus coming to the surface in mid April (Williams \& Wallace 1975).

In contrast, in the Norwegian Sea (Stn $\mathrm{M}, 66^{\circ} \mathrm{N}$, $\left.2^{\circ} \mathrm{E}\right)$, Calanus finmarchicus arrives at the surface at the same time or even earlier than it does south of Iceland (Østvedt 1955, Lie 1968, Wiborg 1978), whereas the phytoplankton bloom does not occur until mid May (Halldal 1953, Dale 1995).

The objective of this work was to study feeding of Calanus finmarchicus in the open sea, from the arousal of the population until the development and decline of the spring phytoplankton bloom, focusing on the influence of environmental conditions, feeding activity before the bloom, the increase in feeding during the bloom, and the contribution of non-phytoplanktonic carbon sources and the effect of those factors on the carbon content of the animal.

\section{MATERIALS AND METHODS}

Stn $\mathrm{M}$ (Mike), $66^{\circ} \mathrm{N}$ and $2^{\circ} \mathrm{E}$ (Fig. 1), has been employed as a permanent weather station since 1948. The weathership remains in an area of about 2.5 miles radius around this position for $28 \mathrm{~d}$ before taking $3 \mathrm{~d}$ to make a port call to change crew and re-supply. The depth is about $2000 \mathrm{~m}$, but due to the slope, important variations in depth can be found in the drifting area $(1500$ to $3000 \mathrm{~m})$. The station is situated on the western edge of the Norwegian Atlantic current, close to the frontal area with Arctic waters transported by the Iceland East current (Mosby 1950)

Samples were taken from 22 March to 9 June 1997. Measurements made on a daily basis were CTD profiles, total chlorophyll a concentration (chl a), gut fluorescence and, with some exceptions, individual carbon. and nitrogen content of Calanus finmarchicus. Sam-

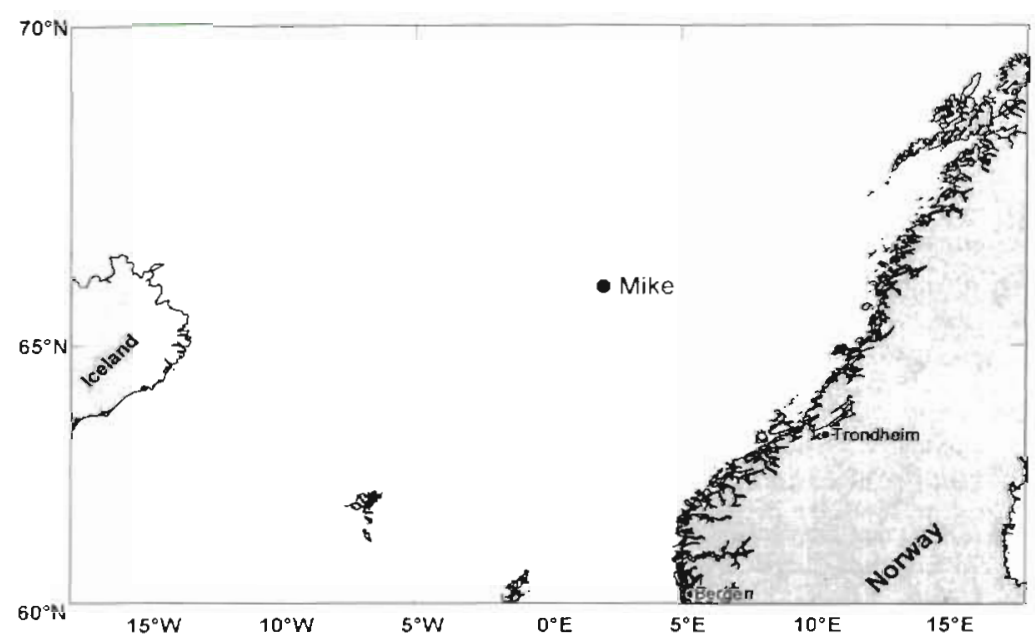

Fig. 1 The Norwegian Sea with the position of Stn M (Mike) ples for fractionated chl a (>5 $\mu \mathrm{m})$, pigment profiles by HPLC (methods of Barlow et al. 1997), total particulate carbon (TPC) and total particulate nitrogen (TPN) were taken once a week at 5,10,20,30,40,50 and $60 \mathrm{~m}$. Additionally several incubation experiments were performed to estimate feeding rates on ciliates.

Daily CTD (Seabird SB19) profiles were performed to $200 \mathrm{~m}$, except on the days when HPLC and TPC vertical distribution samples were taken, then the profile was to $1200 \mathrm{~m}$. Samples for chl a were taken with a rosette at $5,10,20,30,40,50,60,80$ and $100 \mathrm{~m}$, filtered onto a Whatman GF/F filter (total chl a) or Nuclepore membrane filter ( $>5 \mu \mathrm{m}$ chl a) and measured by fluorescence after $24 \mathrm{~h}$ extraction in $90 \%$ acetone (Parsons et al. 1984). WP2 nets $(500 \mu \mathrm{m})$ from $100 \mathrm{~m}$ to the surface were taken to collect animals for gut fluorescence at 09:00 and 21:00 h (22:00 h in the May-June period). Samples for gut fluorescence were immediately frozen in liquid nitrogen. Between 3 and 5 replicates of 10 adult female Calanus finmarchicus were sorted under a stereomicroscope, placed in $7 \mathrm{ml}$ of $90 \%$ acetone and the gut fluorescence measured after $24 \mathrm{~h}$ extraction. Estimates of body carbon and nitrogen were made on replicates of $10 \mathrm{C}$. finmarchicus from the same samples. Prosome lengths of adult females were measured and the specimens were dried at $50^{\circ} \mathrm{C}$ and then analyzed in a Carlo Erba $\mathrm{CN}$ analyzer

Phytoplankton ingestion was estimated from gut fluorescence following the method of Mackas \& Bohrer (1976): $I=G f \times G C R C$, where $I$ is ingestion, $G f$ is the gut fluorescence and GCRC is the gut clearance rate which was estimated from the temperature (Dam \& Peterson 1988). No correction was made for possible pigment destruction. Filtration rates on phytoplankton were estimated by dividing the ingestion by the chl a concentration: $F=I / \mathrm{chl} a$. In order to maintain a conservative approach to estimating $F$ we used the maximum chl a concentration in the mixed layer The C:chl a ratio was calculated following Banse (1977) from the slope of the TPC-chl a regression. Therefore chl a was converted into carbon using a C:chl a ratio of 62 .

The marker pigments measured were chlorophyll $b$, alloxanthin, 19-hexanoyloxyfucoxanthin, fucoxanthin, 19-butanyloxycofucoxanthin and peridinin. The contribution of the different phytoplankton groups to chl a was estimated using CHEMTAX (Mackey et al. 1996).

During the study period the majority of the Calanus finmarchicus population remained in the upper $50 \mathrm{~m}$ during the day (Irigoien et al. 1997). Consequently, we assumed water from the upper layer 
$(5 \mathrm{~m})$ to be representative of the feeding rates on heterotrophic microplankton. Feeding rates on ciliates and heterotrophic dinoflagellates were estimated by incubating 1 to 5 female $C$. finmarchicus in 11 bottles filled with water from $5 \mathrm{~m}$. Three to five replicates and 2 control bottles were incubated for 24 h at sea surface temperature and rotated intermittently. Two experiments were performed before the bloom, 2 during the bloom and 1 after the bloom. Samples of $200 \mathrm{ml}$ were taken from incubation and control bottles at time 0 and time $t$ and fixed with acid Lugol at 10\% final concentration (Stoecker et al. 1994). Subsamples of $100 \mathrm{ml}$ were settled (Utermöhl) and counted with an inverted microscope. Only experiments in which the reduction in ciliate numbers from the control to the grazing bottle was less than $40 \%$ were considered for calculation. To estimate ingestion rates, ciliates were measured and the carbon content was calculated from cell volume using a factor of $0.21 \mathrm{pg} \mathrm{C} \mathrm{m}^{-3}$ (Ohman \& Runge 1994). Mesodinium sp., a ciliate which is considered to be mixotrophic (having $\mathrm{chl}$ a), forms a significant fraction of the ciliate population and should appear in the gut fluorescence measurement. However, as the C:chl a ratio for Mesodinium is likely to be very different from that for phytoplankton and as high as 250 (Harbour pers. comm.), and considering also that ciliate ingestion appeared to be minor in comparison with phytoplankton, we took the conservative approach of including Mesodinium in the ciliate ingestion. Heterotrophic dinoflagellates were separated from autotrophic forms according to taxonomical considerations (Lessard \& Swift 1986, Burkill et al. 1993). Filtration and ingestion rates in the incubations were calculated following Frost (1972).

Ciliate and heterotrophic dinoflagellate abundance were measured in the same way from $5 \mathrm{~m}$ samples taken on 19 occasions throughout the sampling period.

Meteorological data (air temperature, wind speed and direction) and wave height (measured with a shipborne wave recorder MK 4 system) were kindly provided by the captain of the weathership 'Polarfront' (Stn $M$ )

\section{RESULTS}

\section{Hydrography}

Weekly measurements to $1000 \mathrm{~m}$ : For the first period of our sampling program, the 35 psu salinity isohaline, which defines Atlantic water in the Norwegian Sea, was at about $300 \mathrm{~m}$, with a strong intrusion of deeper water by the beginning of April $(>100 \mathrm{~m})$. From the end of April to June the 35 psu isohaline was about $400 \mathrm{~m}$ deep. Some oscillations in the depth of the Atlantic water layer could be detected but none were as strong as the one measured in the previous period. A strong gradient in temperature was related to the interface between Atlantic waters and waters of mixed Atlantic and Arctic origin. The 35 psu isohaline corresponded to a temperature of 3 to $4^{\circ} \mathrm{C}$ as previously described by Mosby (1950). These hydrological features indicate that all of the measurements presented in this work were carried out in Atlantic waters.

Daily measurements to $200 \mathrm{~m}$ : The Atlantic water layer $(200 \mathrm{~m})$ at $\mathrm{Stn} M$ was generally well mixed (Fig 2). By the middle of May, a thermocline started to develop at a depth around 30 to $50 \mathrm{~m}$. Pronounced stratification was established by June with mixing restricted to the upper $30 \mathrm{~m}$. The temperature at the surface $(5 \mathrm{~m})$ increased from $5.5^{\circ} \mathrm{C}$ in March to $8.3^{\circ} \mathrm{C}$ at the end of the sampling period. The onset of the thermocline was clearly related to changes in atmospheric conditions. By the beginning of May the air temperature started to increase from around $6^{\circ} \mathrm{C}$ to $8^{\circ} \mathrm{C}$, wind speeds weakened from a mean value of around 20 to 25 knots to less than 15 knots and the wave height decreased from values ranging from 2 to $4 \mathrm{~m}$ to values around $1 \mathrm{~m}$.

\section{Pigment distribution}

The chl a concentration remained very low $(<0.5 \mu \mathrm{g}$ $\mathrm{l}^{-1}$ ) during March and April (Fig. 3). The phytoplankton bloom occurred by 10 May (Fig. 3) and its maximum
Fig. 2. Temperature $\left({ }^{\circ} \mathrm{C}\right)$ profiles ( 0 to $200 \mathrm{~m}$ ) at $\mathrm{Stn} M$ from 22 Mar to 9 Jun 1997. Data from 13 to 28 April are missing due to technical problems with the CTD

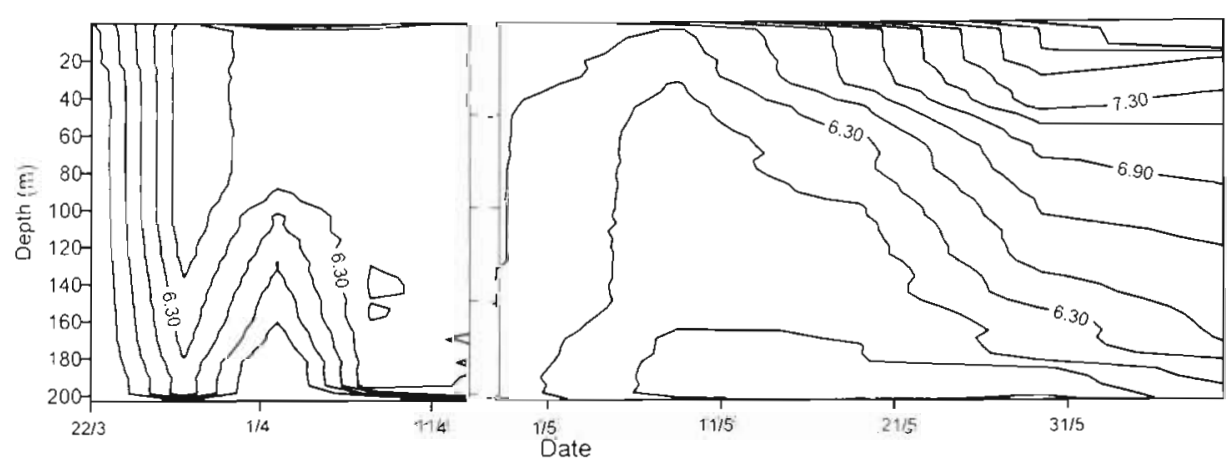




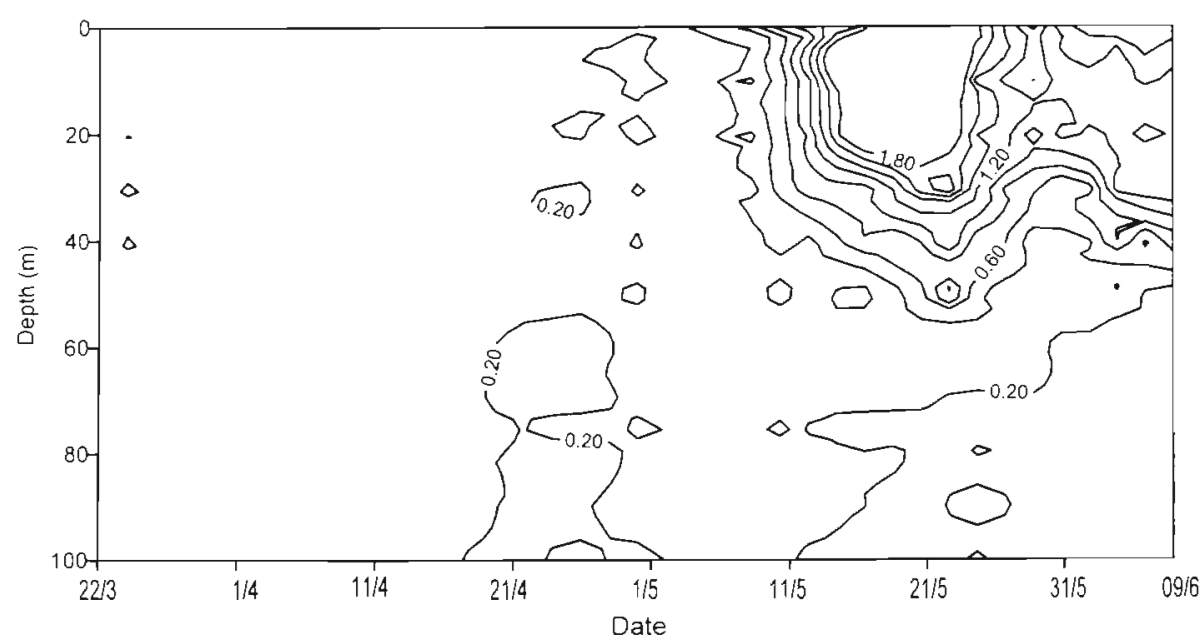

Fig. 3. Vertical distribution of chl a $(0$ to $100 \mathrm{~m})$ at Stn $M$ from 22 Mar to 9 Jun 1997

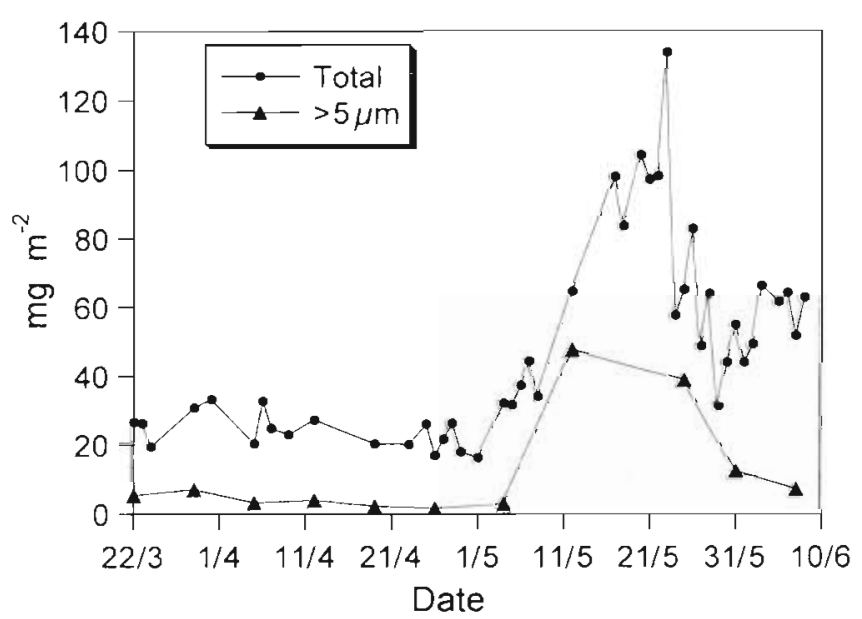

Fig. 4. Integrated $(0$ to $100 \mathrm{~m})$ total $\mathrm{chl} a(\bullet)$ and fractionated $(>5 \mu \mathrm{m})$ chl a (4) at Stn M from 22 Mar to 9 Jun 1997

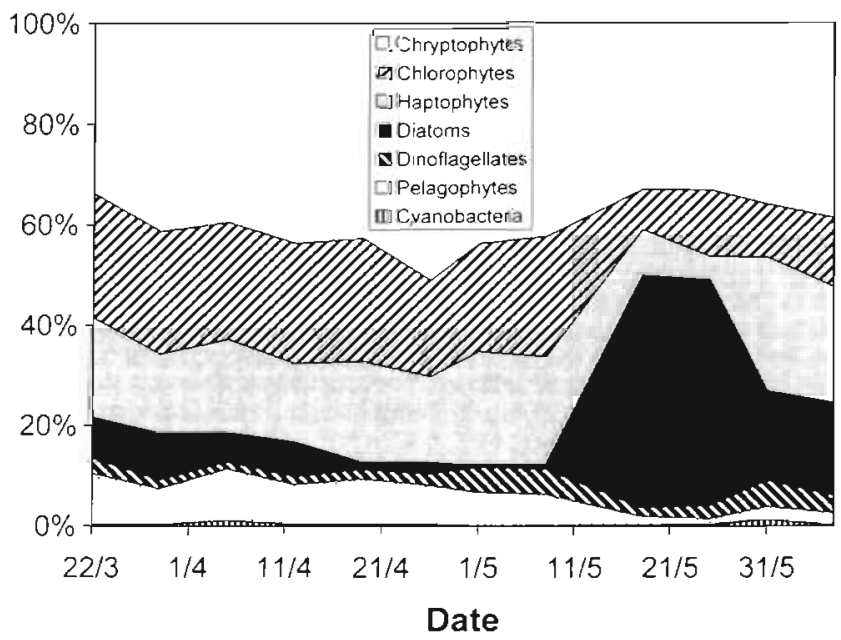

Fig. 5. Percentage contribution of the different phytoplankton groups to chl a for integrated values from surface to $60 \mathrm{~m}$ $\left(3 \mu \mathrm{g}^{-1}\right)$ coincided with the onset of stratification. The bloom appeared to be restricted to the upper $30 \mathrm{~m}$; waters deeper than $40 \mathrm{~m}$ showed lower concentrations of chl a $\left(<0.4 \mathrm{\mu g} \mathrm{l}^{-1}\right)$. The chl a concentration decreased by 25 May to remain around $1.5 \mu \mathrm{g} \mathrm{l}^{-1}$ in the upper layer. The percentage of chl a greater than $5 \mu \mathrm{m}$ was low in the March to mid May period, $<20 \%$, but increased significantly during the phytoplankton bloom, reaching $80 \%$ at $30 \mathrm{~m}$ (Fig. 4).

Fig. 5 presents the contributions of the different phytoplankton groups in terms of chl a to the integrated $(0$ to $60 \mathrm{~m}$ ) chl a concentration. The percentage contribution of different phytoplankton groups was constant for the March to April period with a dominance of green algae $(\sim 40 \%)$, haptophytes ( $30 \%)$ and cryptophytes $(-25 \%)$.

Diatoms $(-30 \%)$, cryptophytes $(-30 \%)$ and dinoflagellates $(\sim 15 \%)$ were dominant during the bloom. After the bloom small flagellates became predominant again (Fig. 5). Chl a measured by fluorometry and by HPLC were well correlated: HPLC chl $a=1.03$ Fluo chl $a-0.06\left(r^{2}=0.9, p<0.05, n=74\right)$.

Consistent with phytoplankton dynamics, the results will be presented in 3 periods: pre-bloom (22 March to 10 May), during the bloom (11 May to 29 May) and post-bloom (30 May to 9 June).

\section{Particulate carbon and nitrogen}

TPC concentration decreased from the end of March to April and increased again during the bloom. TPC concentration ranged from $137 \mathrm{\mu g} \mathrm{l}^{-1}$ by mid April at $100 \mathrm{~m}$ to $390 \mu \mathrm{g} \mathrm{l}^{-1}$ by the end of May at $10 \mathrm{~m}$. TPN followed the same pattern with values ranging from $18 \mu \mathrm{g}$ $\mathrm{l}^{-1}$ by mid April at $100 \mathrm{~m}$ to $51 \mu \mathrm{g} \mathrm{l}^{-1}$ by the end of May at $10 \mathrm{~m}$. The $\mathrm{C}: \mathrm{N}$ ratio measured at different depths ranged from 6 to 8.2 with a mean value of 7.2 and did 
not show any trend in relation to depth, season or phytoplankton concentration.

TPC was related to chl a by TPC $=190.34+62 \mathrm{chl} a$ $\left(r^{2}=0.44, p<0.01, n=92\right)$. The intercept of this equation indicates a high proportion of carbon unrelated to phytoplankton. After subtracting the phytoplanktonic carbon (with the slope of the previous regression) from the total particulate carbon, $185 \mu \mathrm{g} \mathrm{I}^{-1}$ not related to phytoplankton remained before the bloom, $206 \mu \mathrm{g} \mathrm{l}^{-1}$ during the bloom and $170 \mu \mathrm{g} \mathrm{l}^{-1}$ after the bloom. However, the differences are not significant (Mann-Whitney, $p>0.05$ ) and this residual carbon does not appear to be related to other factors like depth or chl a concentration.

\section{Heterotrophic microplankton}

The mean ciliate biomass increased from $0.36 \mu \mathrm{g} \mathrm{C}^{-1}$ ( 1.4 cells $\left.\mathrm{ml}^{-1}\right)$ before the bloom to $4 \mathrm{\mu gC} \mathrm{I}^{-1}(7.9$ cells $\mathrm{ml}^{-1}$ ) during the bloom, decreasing again after the

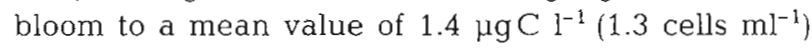
(Fig. 6). Before the bloom the population was largely dominated by Strombidium type ciliates, comprising $96 \%$ of the total population. However they decreased to $85 \%$ during the bloom and $63 \%$ after the bloom. Mesodinium type ciliates increased significantly to $13 \%$ during the bloom and $35 \%$ after the bloom.

The mean concentration of heterotrophic dinoflagellates decreased from 1.1 cells $\mathrm{ml}^{-1}\left(0.6 \mu \mathrm{g} \mathrm{C} \mathrm{l}^{-1}\right)$ before the bloom to 0.4 cells ml ${ }^{-1}\left(0.1 \mu \mathrm{gCl}^{-1}\right)$ and to 0.13 cells $\mathrm{ml}^{-1}\left(0.01 \mu \mathrm{gC}^{-1}\right)$ after the bloom. In terms of percentage the dominant groups were small peridinians (45 to $70 \%$ ), Gyrodinium (13 to $16 \%$ ) and Katodinium (10 to $20 \%)$.

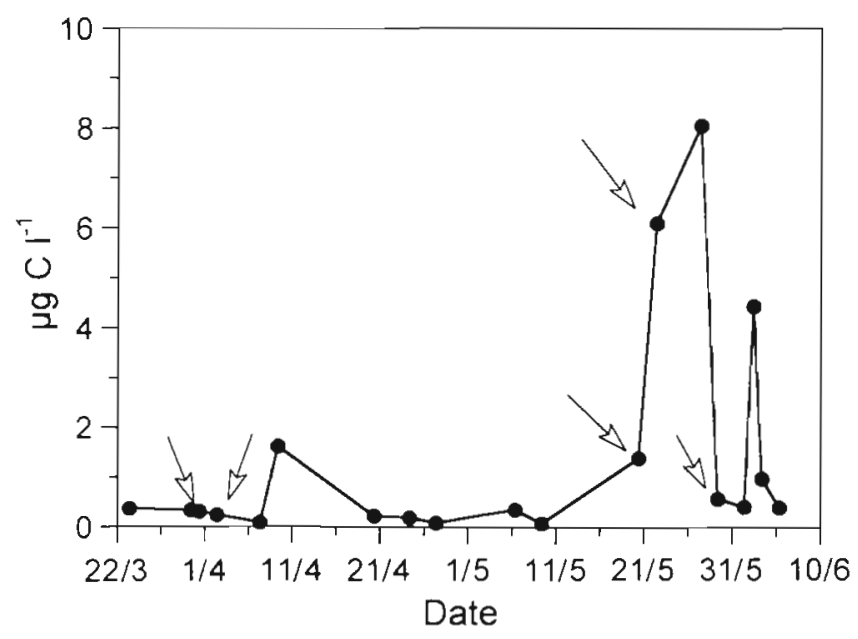

Fig. 6. Time course of the carbon concentration of ciliates ( ) at $5 \mathrm{~m}$ depth from 22 Mar to 9 Jun 1997. Arrows indicate when experiments on ciliate ingestion were done

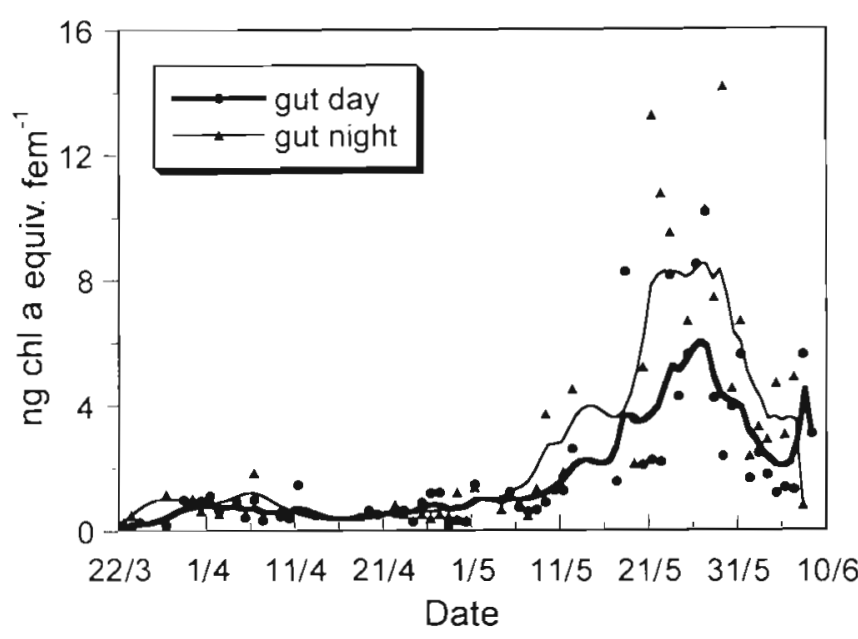

Fig. 7. Calanus finmarchicus. Time course of gut fluorescence at Stn M from 22 Mar to 9 Jun 1997. (•) Day values; ( $\mathbf{(})$ night values. Lines represent smoothed data

Table 1. Calanus finmarchicus females. Mean and standard error (SE) of the day and night gut fluorescence values for the pre-bloom, bloom and post-bloom periods and probability of significant difference tested with a Mann-Whitney test.

\begin{tabular}{|lccccc|}
\hline & \multicolumn{2}{c}{ Day } & \multicolumn{2}{c}{ Night } & Difference \\
& Mean & SE & Mean & SE & $p$ \\
\hline Pre-bloom & 0.7 & $(0.06)$ & 0.9 & $(0.15)$ & $p=0.20$ \\
Bloom & 4.5 & $(0.76)$ & 7.8 & $(1.3)$ & $p=0.02$ \\
Post-bloom & 2.8 & $(0.54)$ & 3.7 & $(0.57)$ & $p=0.20$ \\
\hline
\end{tabular}

\section{Gut fluorescence}

Gut fluorescence values were related to $100 \mathrm{~m}$ integrated chl a $\left(\mathrm{r}^{2}=0.39, \mathrm{p}<0.05\right.$ for daytime data and $\mathrm{r}^{2}$ $=0.30, \mathrm{p}<0.05$ for night-time data), with low values from March to April, a significant increase during the bloom and decrease after the bloom (Fig. 7, Table 1). On average gut pigment levels were higher during the night than during the day but the difference was only significant during the bloom (Fig. 7, Table 1).

\section{Feeding rates on phytoplankton}

The mean phytoplankton ingestion rates estimated from gut fluorescence are presented in Table 2 . When plotted against chl a, either integrated or in the surface, ingestion does not seem to reach saturation (Fig. 8). When using total chl a values, filtration rates ranged from 23 to $294 \mathrm{ml}$ ind.$^{-1} \mathrm{~d}^{-1}$ with a mean value of $88 \mathrm{ml}$ ind $\mathrm{d}^{-1} \mathrm{~d}^{-1}$ before the bloom, from 41 to $357 \mathrm{ml}$ ind. ${ }^{-1} \mathrm{~d}^{-1}$ with a mean value of $157 \mathrm{ml}$ ind ${ }^{-1} \mathrm{~d}^{-1}$ during the bloom and from 49 to $140 \mathrm{ml}$ ind.$^{-1} \mathrm{~d}^{-1}$ with a mean 
Table 2. Calanus finmarchicus females. Mean phytoplankton and ciliate ingestion rates for the pre-bloom, bloom and post-bloom periods expressed in $\mathrm{ngC}$ fem ${ }^{-i} \mathrm{~d}^{-1}$ and as percentage of the carbon body weight. In parentheses, the standard error of the mean for the phytoplankton ingestion is given

\begin{tabular}{|lccccc|}
\hline $\begin{array}{c}\text { Phytoplankton ingestion } \\
\text { (ngC fem }{ }^{-1} \mathrm{~d}^{-1} \text { ) }\end{array}$ & $\begin{array}{c}\text { \% of body } \\
\text { carbon }\end{array}$ & $\begin{array}{c}\text { Ciliate ingestion } \\
\text { (ngC fem }{ }^{-1} \mathrm{~d}^{-1} \text { ) }\end{array}$ & $\begin{array}{c}\% \text { uf body } \\
\text { carbon }\end{array}$ & $\begin{array}{c}\% \text { ciliates/ } \\
\text { phytoplankton }\end{array}$ \\
\hline Pre-bloom & $1433(190)$ & 2.3 & 32 & 0.05 & 2 \\
Bloom & $14295(2016)$ & 30 & 836 & 1.8 & 6 \\
Post-bloom & $7587(915)$ & 14 & 226 & 0.4 & 3 \\
\hline
\end{tabular}

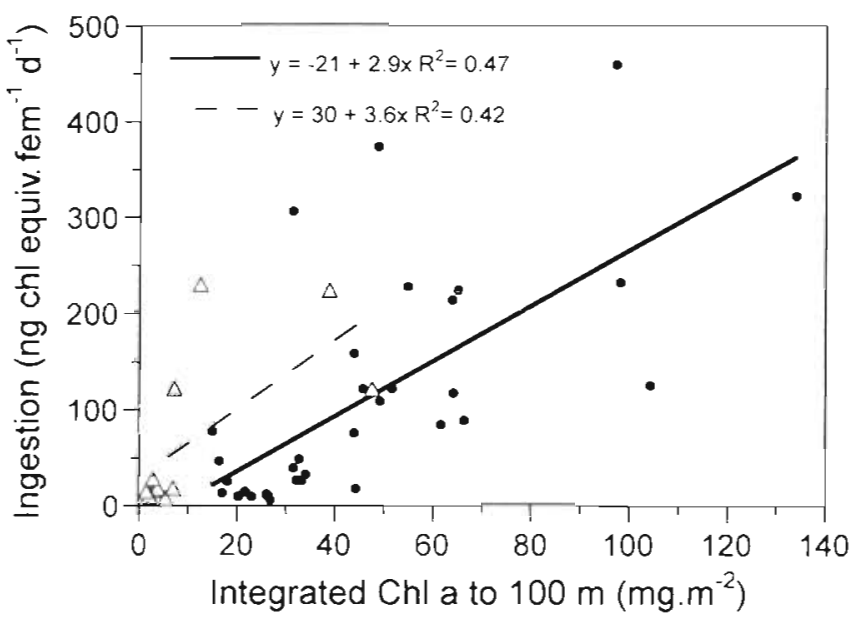

Fig. 8. Calanus finmarchicus. Relationship between upper $100 \mathrm{~m}$ integrated chl a concentration and chl a ingestion at Stn M. (•) Total chl $a_{i}(\Delta)>5 \mu \mathrm{m} \operatorname{chl} a$

value of $106 \mathrm{ml}$ ind.$^{-1} \mathrm{~d}^{-1}$ after the bloom. If we consider only chl a $>5 \mu \mathrm{m}$, filtration values ranged from 97 to $903 \mathrm{ml}$ ind.$^{-1} \mathrm{~d}^{-1}$ with a mean value of $420 \mathrm{ml}$ ind.-1 $\mathrm{d}^{-1}$ before the bloom, from 59 to $187 \mathrm{ml}$ ind.-1 $\mathrm{d}^{-1}$ with a mean value of $123 \mathrm{ml}$ ind ${ }^{-1} \mathrm{~d}^{-1}$ during the bloom and from 680 to $761 \mathrm{ml}$ ind.-1 $\mathrm{d}^{-1}$ with a mean value of $721 \mathrm{ml}$ ind.-1 $\mathrm{d}^{-1}$ after the bloom.

From zooplankton biomass data (Klenke unpubl.) the grazing impact in the upper $100 \mathrm{~m}$ was estimated to be about $1 \%$ of the phytoplankton standing stock before the bloom, $15 \%$ during the bloom and $5 \%$ after the bloom.

\section{Feeding rates on heterotrophic microplankton}

Clearance rates on ciliates were high, ranging from 74 to $545 \mathrm{ml} \mathrm{fem} .^{-1} \mathrm{~d}^{-1}$ (Fig. 9), with ingestion values from 8.5 to $56 \mathrm{ngC} \mathrm{fem} .^{-1} \mathrm{~d}^{-1}$ before the bloom, 739 to $933 \mathrm{ngC}$ fem. ${ }^{-1} \mathrm{~d}^{-1}$ during the bloom and $226 \mathrm{ngC}$ fem. ${ }^{-1} \mathrm{~d}^{-1}$ after the bloom (Fig. 9)

Clearance rates on heterotrophic dinoflagellates ranged from 54 to $221 \mathrm{ml} \mathrm{fem}^{-1} \mathrm{~d}^{-1}$, but due to the low concentration in the water carbon ingestion was low, from 14 to $73 \mathrm{ngC} \mathrm{fem} .^{-1} \mathrm{~d}^{-1}$.

\section{Carbon content and $\mathrm{C}: \mathrm{N}$ ratio}

The carbon content of adult females in the population decreased significantly during the pre-bloom period, remained constant during the bloom and increased slightly after the bloom (Fig. 10a). The C:N ratio follows the same pattern with a reduction from values of around 8 at the beginning of the sampling period to values of around 4 at the end of the prebloom period (Fig. 10b). Neither the $\mathrm{N}$ content (mean value $10.9 \mathrm{mg} \mathrm{N} \mathrm{em}^{-1}$ ) nor the prosome length of the females (mean value $2.5 \mathrm{~mm}$ ) showed significant variations during the sampling period.

\section{DISCUSSION}

The phytoplankton bloom at Stn $M$ appears to be clearly related to the onset of the thermocline in the upper layer Increase in the compensation depth and

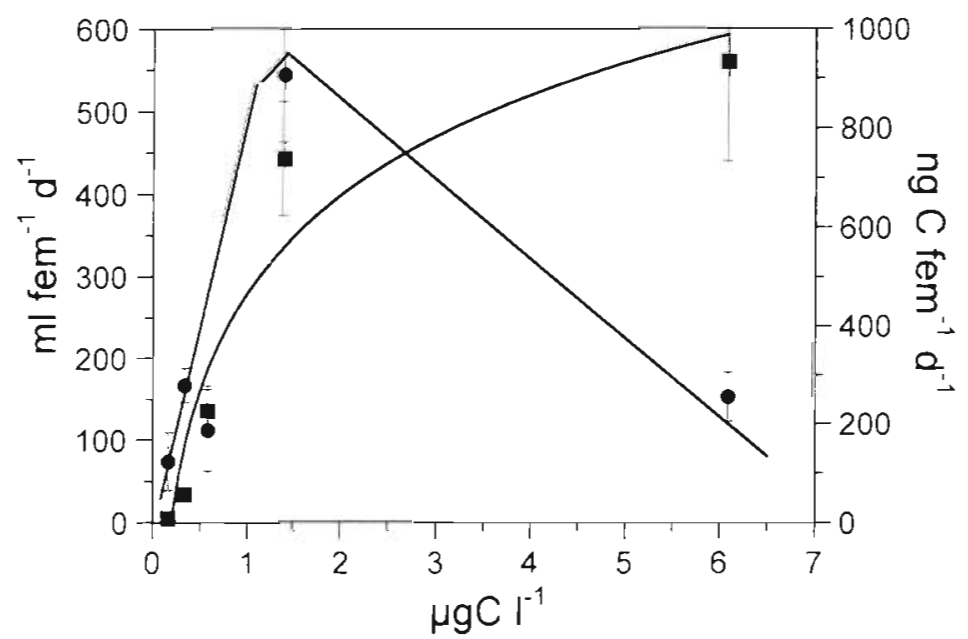

Fig. 9. Calanus finmarchicus. Ingestion ( $\mathbf{0}$ ) and filtration (-) rates of females feeding on ciliates as a function of ciliate concentration. Vertical bars indicate standard error of the mean 
stability have long been recognised as decisive factors in the spring bloom development at Stn $M$ (Sverdrup 1953. Halldal 1953). This is due to a reduction in the mixing depth /euphotic depth ratio as a consequence of stratification (Sverdrup 1953).

The bloom was also characterized by a change in the composition and cell size of the phytoplankton population from small flagellates and green algae to a predominance of diatoms (mainly Rhizosolenia delicatula).

It is generally believed that cells smaller than $5 \mu \mathrm{m}$ are not available to Calanus (Marshall \& Orr 1955) and in fact Gifford et al. (1995), in the North Atlantic, showed that the impact of $C$. finmarchicus grazing on cells smaller than $20 \mu \mathrm{m}$ was negligible Nevertheless, during our study, even taking the conservative approach of considering the animals feeding all the time in the maximum of chl $a$, the filtration rates on $>5 \mu \mathrm{m}$ chl a appear to be extremely high before and after the bloom, only comparable to the values obtained by Paffenhöfer (1971) with C. helgolandicus feeding on Gymnodinium splendens (60 $\mathrm{\mu m}$ maximum width dinoflagellate). Those unrealistic results suggest that at low chl a concentrations small cells should also be considered as a possible food source.

Only during the bloom were night-time gut fluorescence levels significantly higher than daytime values. For practical reasons, daily sampling times were limited and it is difficult to determine how representative the gut fluorescence measured at 09:00 and 21:00 h was of the maximum night and minimum day values, with the increasing day length from March to June. However, as the study was done during a period when the day length was increasing, the effect of higher light levels for the 'night' sample was likely to have been a reduction in the gut fluorescence, so the measured difference during the bloom is likely to be smaller than the real one, rather than an artifact. Mechanisms controlling diel feeding rhythms are still not well understood but risk of predation and hunger have been proposed as the most relevant factors. Johnsen \& Jacobsen (1987) suggested that diel feeding rhythms and vertical migration reflect a trade-off between 2 conflicting interests: avoiding the increased risk of predation when feeding (Tiselius et al. 1997) and risking starvation (Huntley \& Brooks 1982). Results on this subject are contradictory, with a number of studies providing evidence that food limitation
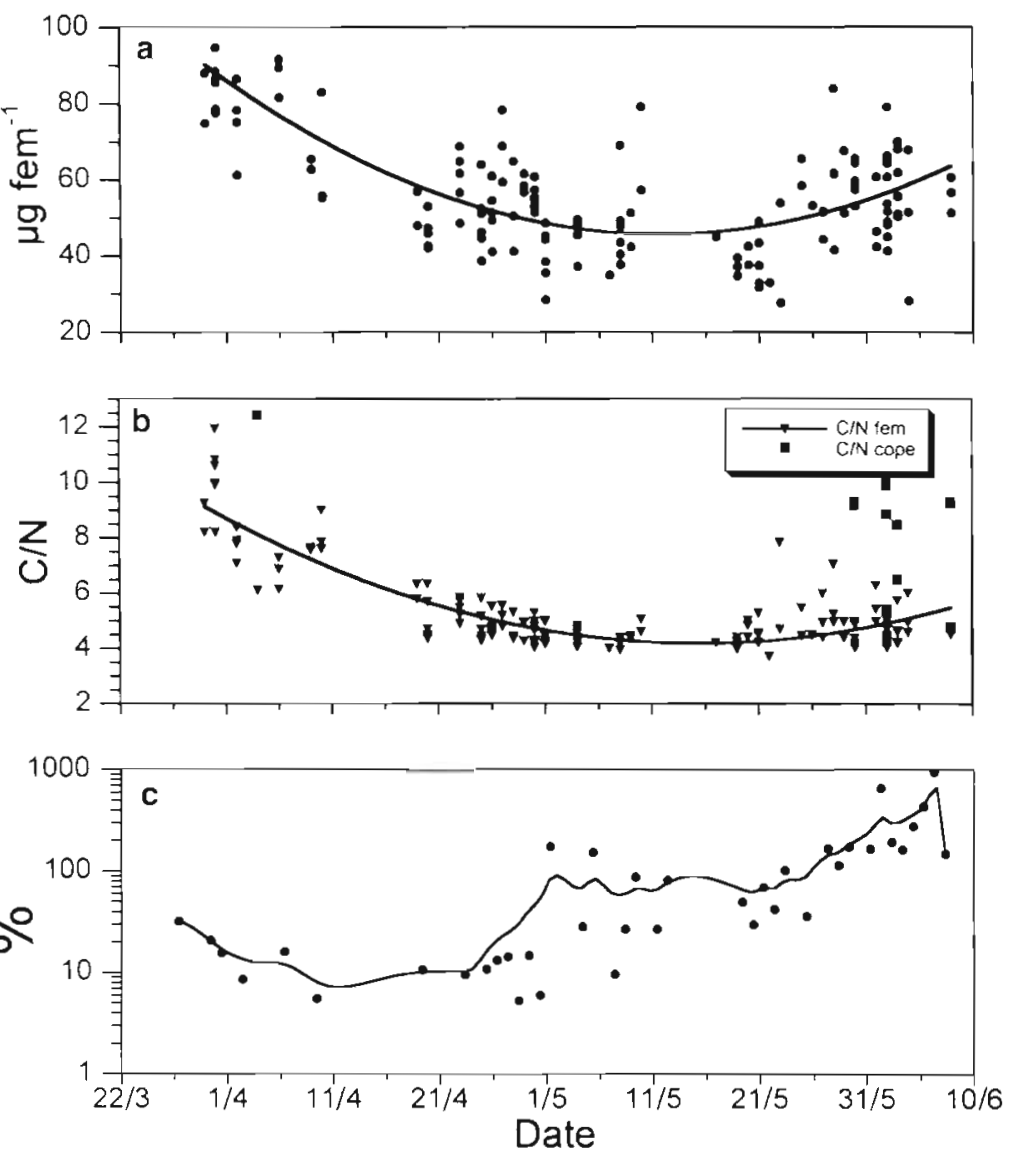

Fig. 10. Calanus finmarchicus. Time course (a) of female carbon content, (b) C:N ratio and (c) percentage of carbon requirements for egg production covered by phytoplankton ingestion at Stn M from 22 Mar to 9 Jun the same samples. Fitted lines are $y=2.81 \times 10^{6}-0.019 x+3.26 \times 10^{-11} x^{2}$ $\left(\mathrm{r}^{2}=0.46, \mathrm{n}=145\right.$ ) for carbon content (a) and $y=2.89 \times 10^{5}-0.002 x+3.3 \times$ $10^{-12} x^{2}\left(r^{2}=0.73, n=145\right)$ for $C: N$ ratio (b). In (c) the line represents smoothed data

may alter or suppress diel migratory or feeding rhythms (Boyd et al. 1980, Huntley \& Brooks 1982, Dagg 1985, Dagg \& Walser 1987) whereas other studies show that feeding rhythms are maintained at low food concentration (Dagg \& Grill 1980, Simard et al. 1985. Drits et al. 1990, Durbin et al. 1990). Our results seem to confirm the previous hypothesis with night gut contents on average $40 \%$ higher during the bloom against $20 \%$ before and after the bloom.

Gut fluorescence and ingestion rates measured during this study were within the range reported in the literature for Calanus finmarchicus (Tande \& Bamstedt 1985, Smith \& Lane 1988. Tiselius 1988, Ohman \& Runge 1994, Cowles \& Fessenden 1995, Durbin et al. 1995, 1997). An important controversy remains about the percentage of pigments destroyed in the gut of the copepods, with values ranging from 0 to $95 \%$ (see review in Pasternak 1994). On the other hand, when 
Table 3. Calanus finmarchicus females. Egg production rate (EPR), standard error of the mean (SE), carbon requirements for egg production (see text for explanation), total ingestion (phytoplankton + ciliates) and percentage of the carbon requirements covered by ingestion. Egg production data from Niehoff et al. (1998)

\begin{tabular}{|c|c|c|c|c|}
\hline & $\begin{array}{c}\operatorname{EPR}(\mathrm{SE}) \\
\left.\text { (eggs fem. }^{-1} \mathrm{~d}^{-1}\right)\end{array}$ & $\begin{array}{l}\text { Carbon for EPR } \\
\left(\text { ngC fem }{ }^{-1} d^{-1}\right)\end{array}$ & $\begin{array}{c}\text { Ingestion } \\
\text { chl } a+\text { ciliates } \\
\left(\text { ngC fem.-1 } d^{-1}\right)\end{array}$ & $\% \mathrm{I} / \mathrm{EPR}$ \\
\hline Pre-bloom & $7.9(0.7)$ & 6380 & 1465 & 23 \\
\hline Bloom & $24.8(2.6)$ & 19000 & 15130 & 80 \\
\hline Post-bloom & $3 \quad(0.6)$ & 2300 & 7800 & 340 \\
\hline
\end{tabular}

the sampling for the ciliate concentration was more intensive and the estimates correspond to those found in the literature (see Table 1 in Tiselius 1989). Moreover, heterotrophic contribution to the diet corresponds with that found by Ohman \& Runge (1994) at similar ciliate concentration, 3.2 to $5.1 \%$ of the total diet with 2.4 to 3.3 ciliates $\mathrm{ml}^{-1}$.

The pattern of both carbon content and $C: N$ ratio, which closely follow the percentage of carbon requirements covered by phytoplankton ingestion

directly comparing different methods to estimate feeding, reliable results are obtained with gut fluorescence (Baars \& Fransz 1984, Tiselius 1988, Peterson et al. 1990, see also Pasternak 1994). As an example, the ingestion measured here was equal to or higher than the ingestion calculated from incubation experiments during the same cruise which was $1.1,15.4$ and $2 \%$ of the carbon body weight per day for the pre-bloom, bloom and post-bloom periods respectively (MeyerHarms et al. unpubl.). In addition, if the chl a ingestion was seriously underestimated, one would expect low filtration rates because of not taking into account the result of an important part of the activity. On the contrary, measured filtration rates on phytoplankton were rather high and a significantly higher ingestion at the same chl a concentration would lead to unrealistic filtration rates even if estimated on total chl a. In fact, we observed an ingestion of $2 \%$ of the body carbon weight per day at chl a concentrations lower than the previously estimated feeding threshold for C. finmarchicus by radioactive tracer methods (Daro 1980). However, it must be taken into account that due to some of the flaws in the methods (inadequate diel sampling, gut clearance rate estimated from the temperature or possible changes in the $C$ :chl a ratio) the ingestion values must be considered as a range or approximate values rather than absolute values.

In order to estimate whether ingestion (phytoplankton + ciliates) was enough to maintain egg production, we estimated carbon requirements for the different periods from egg production rates measured at the same time as the ingestion measurements (Niehoff et al. 1998), assuming a carbon content of $230 \mathrm{ng} \mathrm{C}$ $\mathrm{egg}^{-1}$ and a gross growth efficiency of $30 \%$ (Hirche 1996) (Table 3, Fig. 10c). If, during the bloom, measured ingestion (phytoplankton + ciliates) nearly covered carbon requirements and post-bloom ingestion was in excess, pre-bloom ingestion was clearly not enough to cover egg production carbon requirements (Table 3).

The number of experiments on ciliate ingestion was low and could have been be a source of error; however.
(Fig, 10), suggests that an important percentage of the egg production carbon requirements before the bloom came from lipid storage. The decrease in carbon content is important, about $47 \%$ in a period of $50 \mathrm{~d}$, but still lower than that reported by Ohman \& Runge (1994) in conditions of total starvation, $\sim 17 \%$ of the total lipids in $3.5 \mathrm{~d}$. The $\mathrm{C}: \mathrm{N}$ ratio changed from values typical for Arctic or Antarctic species to values close to those of temperate coastal species without, or wih very low, lipid storage (Ikeda 1974).

Similar situations where the carbon content and $C: N$ ratio or the lipid storage decreased in a similar way before the phytoplankton bloom have been reported for Calanus finmarchicus (Tande 1982) and for Antarctic species such as C. propinquus or Metridia gerlachei (Hagen \& Schnack-Schiel 1996). Niehoff \& Hirche (1996) conclude that vitellogenesis 1 is a slow process fuelled by internal lipid storage whereas vitellogenesis 2 is a fast process requiring external inputs. Hagen \& Schnack-Schiel (1996) for C. propinquus and $M$. gerlachei and Plourde \& Runge (1993) for C. finmarchicus also suggested that gonad formation and maturation were fuelled by internal energy reserves, but that major egg-laying activities would probably rely on external sources. This is in agreement with the results of Tande (1982) where the decrease in carbon content and $\mathrm{C}: \mathrm{N}$ ratio coincided with the development of the gonads in CV and females but the final gonad maturation stage in females was only reached in April coinciding with the phytoplankton bloom.

Those previous results seem to indicate that carbon ingestion, either of phytoplankton or microzooplankton, is necessary for the final gonad maturation. It can be hypothesized that egg production should be the result of 2 factors: previous lipid storage, which has a reproductive potential and is represented by the decrease of both carbon content and $\mathrm{C}: \mathrm{N}$ ratio (Tande 1982, this work), and instantaneously available food or actual ingestion, which will explain the relation between ingestion (or chl a concentration) and egg production rate frequently observed (Hirche et al. 1991, 1997, Niehoff et al. 1998) and will provide the 
required external inputs for vitellogenesis 2 . In this way the lack of agreement in the comparison between carbon requirements for egg production and ingestion before the bloom could be explained as due to not taking into account the use of lipid storage during vitellogenesis 1. Further, the difference between ingestion and egg production after the bloom probably contributes to the deposition of lipid storage as shown by the increase in C:N ratio. Unfortunately, estimation of the percentage contribution from lipid storage to egg production from the data we collected is difficult because gonad maturation in Calanus finmarchicus begins at stage V (Niehoff \& Hirche 1996), so estimates of the contribution of lipids to egg production would have to follow the decrease in lipid storage for stage $\mathrm{CV}$ as well. Furthermore, the gross growth efficiency for phytoplankton ingestion is assumed to be around 0.3 , but nothing is known about the efficiency of transforming storage lipids (wax-esters) into egg lipids (triacylglycerols) (Sargent \& Falk-Petersen 1988).

Another possible source of carbon frequently neglected in the open sea is detritus. During our study TPC not related to phytoplankton was around $200 \mathrm{Hg} \mathrm{l}^{-1}$, which in terms of phytoplankton would be a saturating concentration for Calanus pacificus (Frost 1972). Such high concentrations are not unusual. In the North Atlantic, Weeks et al. (1993) found TPC concentrations ranging from 120 to $170 \mu \mathrm{g} \mathrm{l}^{-1}$ where the sum of phytoplankton, bacteria and zooplankton did not exceed $25 \%$ of the TPC. In the English Channel, Holligan et al. (1984) measured detritus concentrations ranging from 102 to $394 \mu \mathrm{g} \mathrm{l}^{-1}$ and even in an oligotrophic sea like the Mediterranean the amount of POC (particulate organic carbon) not related to chl a seems to be around $200 \mu \mathrm{g} \mathrm{l}^{-1}$ or higher (see Table 1 and Fig. 4 in Saiz et al. 1992). However, the bulk of this detrital carbon in the open sea does not appear in microscopic analysis and is considered to be formed by 'structureless' material or 'marine snow' Paffenhöfer \& Strickland (1970) showed that this natural detritus was not ingested by Calanus helgolandicus. Furthermore, during our study egg production was clearly related to the phytoplankton concentration and to the phytoplankton ingestion (Niehoff et al. 1998) whereas the amount of 'detritus' remains constant. So, it is unlikely that detritus plays an important role in the ingestion of $C$. finmarchicus in the Norwegian Sea.

Finally, the estimates given in this and other articles consider the metabolism (e.g. assimilation, gross growth efficiency) of the copepods to be the same at low food concentrations as at high concentrations. However, Landry \& Hassett (1985) showed for Calanus pacificus that parameters like feeding potential, digestive enzyme activity or assimilation efficiency increase in response to chronically low food, suggesting that before the bloom copepods can use the ingested carbon in a more efficient way than during and after the bloom.

Acknowledgements. We thank the Captain and the crew of the 'Polarfront' for their collaboration. We are indebted as well to Bjornar Ellertsen for his excellent help in organising this project, and to Francisco Rey, Hein-Rune Skjoldal and Svein Sundby at the Institute for Marine Reseach in Bergen for their support. We are also grateful to S. Plourde for his comments on previous versions of this manuscript. This work was supported by funding from the European Commision though the TASC project, Contract MAS3-CT95-0039.

\section{LITERATURE CITED}

Astthorsson OS, Gislason A (1997) On the food of capelin in the subarctic waters north of Iceland. Sarsia 82:81-86

Baars MA, Fransz HS (1984) Grazing pressure of copepods on the phytoplankton stock of the central North Sea. Neth J Sea Res 18:120-142

Bainbridge V, McKay BJ (1968) The feeding of cod and red fish larvae. ICNAF Spec Publ 7:187-217

Banse K (1977) Determining the carbon to chlorophyll ratio of natural phytoplankton. Mar Biol 41:199-212

Barlow RG, Cummings DG, Gibb S (1997) Improved resolution of mono and divinyl chlorophylls $a$ and $b$ and zeaxanthin and lutein in phytoplankton extracts using reverse phase C-8 HPLC. Mar Ecol Prog Ser 161:303-307

Boyd C. Smith S, Cowles T (1980) Grazing patterns of copepods in the upwelling system off Peru. Limnol Oceanogr 25:583-596

Burd AC (1963) Recent changes in the recruitment pattern of the 'Downs' herring. Rapp PV Reun Cons Perm Int Explor Mer 154:203-212

Burkill PH, Edwards ES, John AWG, Sleigh MA (1993) Microzooplankton and their herbivorous activity in the northeastern Atlantic Ocean. Deep-Sea Res II 40:479-493

Cowles TJ, Fessenden LM (1995) Copepod grazing and finescale distribution patterns during the marine Light-Mixed Layers experiment. J Geophys Res 100:6677-6686

Cushing DH (1982) Climate and fisheries. Academic Press, New York

Dagg MJ (1985) The effects of food limitation on diel migratory behavior in marine zooplankton. Arch Hydrobiol Beih Ergebn Limnol 21:247-255

Dagg MJ, Grill DW (1980) Natural feeding rates of Centropages typicus females in the New York bight. Limnol Oceanogr 25:583-596

Dagg MJ, Walser WE (1987) Ingestion, gut passage, and egestion by the copepod Neocalanus plumchrus in the laboratory and in the subarctic Pacific Ocean. Limnol Oceanogr $32: 178-188$

Dale T (1995) Plateplanktonets sesongutvikling på Stasjon M i årene 1990-1992. Bergen University, Bergen

Dam HG, Peterson WT (1988) The effect of temperature on the gut clearance rate constant of planktonic copepods. J Exp Mar Biol Ecol 123:1-14

Daro $\mathrm{MH}$ (1980) Field study of the diel feeding of a population of Calanus finmarchicus at the end of a phytoplankton bloom. FLEX '76, 22 May - 5 June. Meteor Forschergeb A Allg, Phys Chem Meeres 22:123-132

Drits AV, Pasternak AF, Tseytlin VB (1990) Investigation of feeding circadian rhythm of antarctic copepod Calanus propinquus. Oceanologia 30:999-1005 
Durbin AG, Durbin EG, Wlodarczyk E (1990) Diel feeding behavior in the marine copepod Acartia tonsa un relation to food availability. Mar Ecol Prog Ser 68:23-45

Durbin EG, Campbell RG, Gilman SL, Durbin AG (1995) Die] feeding behavior and ingestion rate in the copepod Calanus finmarchicus in the southern Gulf of Maine during late spring. Cont Shelf Res 15:539-570

Durbin EG, Runge JA, Campbell RG, Garrahan PR, Casas MC, Plourde S (1997) Late fall-early winter recruitment of Calanus finmarchicus on Georges Bank. Mar Ecol Prog Ser 1.51:103-114

Ellertsen B, Solemdal P, Sundby $S$, Tilseth S, Westgard T, Oiestad V (1981) Feeding and vertical distribution of cod larvae in relation to availability of prey organisms. Rapp PV Reun Cons Int Explor Mer 178:31.7-319

Frost BW (1972) Effects of size and concentration of food particles on the feeding behavior of the marine planktonic copepod Calanus pacificus. Limnol Oceanogr 17(6): 805-815

Gifford DJ, Fessenden LM, Garrahan PR, Martin E (1995) Grazing by microzooplankton and mesozooplankton in the high-latitude North Atlantic Ocean: spring versus summer dynamics. J Geophys Res 100:6665-6675

Hagen W, Schnack-Schiel SB (1996) Seasonal lipid dynamics in dominant Antarctic copepods: energy for overwintering or reproduction? Deep-Sea Res I 43:139-158

Halldal P (1953) Phytoplankton investigations from weather ship $M$ in the Norwegian sea, 1948-49. Hvalrådets Skr 38 : 91

Harris RP (1996) Feeding ecology of Calanus. Ophelia 44 $85-109$

Hirche HJ (1996) The reproductive biology of the marine copepod, Calanus finmarchicus - a review. Ophelia 44: $111-128$

Hirche HJ, Baumann MEM, Kattner G, Gradinger R (1991) Plankton distribution and the impact of copepod grazing on primary production in Fram Strait, Greenland Sea. J Mar Syst 2:477-494

Hirche HJ, Meyer U, Niehoff B (1997) Egg production of Calanus finmarchicus: effect of temperature, food and season. Mar Biol 127:609-620

Holligan PM, Harris RP, Newel.l RC, Harbour DS, Head RN, Linley EAS, Lucas MII, Tranter PRG. Weekley CM (1984) Vertical distribution and partitioning of organic carbon in mixed, frontal and stratified waters of the English Channel. Mar Ecol Prog Ser 14:111-127

Huntley M, Brooks R (1982) Effects of age and food avallability on diel vertical migration of Calanus pacificus. Mar Biol $71: 23-31$

Ikeda T (1974) Nutritional ecology of marine zooplankton Mem Fac Fish Hokkaido Univ 22:1-97

Irigoien X, Head R, Klenke U, Niehoff. B, Meyer-Harms B, Harris R. Hirche HJ (1997) Calanus finmarchicus feeding and reproduction: a high frequency time series at weathership M., Norwegian Sea, during the 1997 spring bloom. In: 1997 ICES Annual Science Conference, Baltimore USA, October 1997. CM 1997/T:53

Johnsen GH, Jacobsen PJ (1987) The effect of food limitation on vertical migration in Daphnia longispina. Limnol Oceanogr 32:873-880

Kane J (1984) The feeding habits of co-occurring cod and haddock larvae from Georges Bank. Mar Ecol Prog Ser 16 : $9-20$

Landry M, Hassett $P$ (1985) Time scales in behavioral, biochemical, and energetic adaptations to food-limiting conditions by a marine copepod. Arch Hydrobiol Beih Ergbn Limnol 21:209-221
Lessard EJ, Swift E (1986) Dinoflagellates from the North Atlantic classified as phototrophic or heterotrophic by epifluorescence microscopy. J Plankton Res 6:1209-1215

Lie U (1968) Variations in the quantity of zooplankton and the propagation of Calanus finmarchicus at station ' $M$ ' in the Norwegian Sea. Fiskeridir Skr Serie Havunders 14(3) $121-128$

Mackas D, Bohrer R (1976) Fluorescence analysis of zooplankton gut contents and an investigation of diel feeding patterns. J Exp Mar Biol Ecol 25:77-85

Mackey MD, Mackey DJ, Higgins HW, Wright SW (1996) CHEMTAX - a program for estimating class abundances from chemical markers: application to HPLC measurements of phytoplankton. Mar Ecol Prog Ser 144:265-283

Maravelias CD, Reid DG (1997) Identifying the effects of oceanographic features and zooplankton on prespawning herring abundance using generalized additive models. Mar Ecol Prog Ser 147:1-9

Marshall SM (1924) The food of Calanus finmarchicus during 1923. J Mar Biol Assoc UK 13:473-479

Marshall SM, Orr AP (1955) On the biology of Calanus finmarchicus VIII. Food uptake, assimilation and excretion in adult and stage $\mathrm{V}$ Calanus. I Mar Bıol Assoc UK 34: $495-529$

Miller CB, Cowles TJ, Wiebe PH, Copley NJ, Grigg H (1991) Phenology in Calanus finmarchicus; hypotheses about control mechanisms. Mar Ecol Prog Ser 72:79-91

Mosby H (1950) Recherches oceanographiques dans la mer de Norvege a la station meteorologique $\mathrm{M}$. Cah Centre Rech Etudes Oceanogr 1:1-7

Niehoff B, Hirche HJ (1996) Oogenesis and gonad maturation in the copepod Calanus finmarchicus and the prediction of egg production from preserved samples. Polar Biol 16 : $601-612$

Niehoff B, Hurche HJ (1997) The reproduction of Calanus finmarchicus in the Norwegian Sea in spring. In: 1997 ICES Annual Science Conference, Baltimore October 1997 ICES CM 1997/T52

Niehoff B, Klenke U, Hirche HJ, Irigoien X, Head RN, Harris RP (1998) A high frequency time series at weathership $M$, Norwegian Sea, during the 1997 spring bloom: the reproduction of Calanus finmarchicus. Mar Ecol Prog Ser (in press)

Ohman MD, Runge JA (1994) Sustained fecundity when phytoplankton resources are in short supply: omnivory by Calanus finmarchicus in the Gulf of St. Lawrence. Limnol Oceanogr 39(1):21-36

Østvedt OJ (1955) Zooplankton investigations from weather ship $\mathrm{M}$ in the Norwegian sea, 1948-49. Hvalrådets Skr 40: 93

Paffenhöfer GA (1971) Grazing and ingestion rates of nauplii, copepodids and adults of the marine planktonic copepod Calanus helgolandicus. Mar Biol 11:286-298

Paffenhofer GA, Strickland JDH (1970) A note on the feeding of Calanus helgolandicus on detritus. Mar Biol 5:97-99

Parsons TR, Maita Y, Lalli CM (1984) A manual of chemical and biological methods for seawater analysis. Pergamon Press, Oxford

Pasternak AF (1994) Gut fluorescence in herbivorous copepods: an attempt to justify the method. Hydrobiologia 292/293:241-248

Peterson W, Painting S, Barlow R (1990) Feeding rates of Calanoides carinatus: a comparison of five methods including evaluation of the gut fluorescence method. Mar Ecol Prog Ser 63:85-92

Plourde S, Runge JA (1993) Reproduction of the planktonic copepod Calanus finmarchicus in the lower St. Lawrence 
estuary: relation to the cycle of phytoplankton production and evidence for a Calanus pump. Mar Ecol Prog Ser 102 : $217-227$

Runge JA (1988) Should we expect a relationship between primary production and fisheries? The role of copepod dynamics as a filter of trophic variability. Hydrobiologia 167/168:61-71

Saiz E, Rodriguer V, Alcaraz M (1992) Spatial distribution and feeding rates of Centropages typicus in relation to frontal hydrographic structures in the Catalan Sea (Western Mediterranean). Mar Biol 112:49-56

Sargent JR, Falk-Petersen S (1988) The lipid biochemistry of calanoid copepods. Hydrobiologia 167/168:101-114

Simard Y, Lacroix G, Legendre L (1985) In situ twilight grazing rhythm during diel vertical migrations of a scattering layer of Calanus finmarchicus. Limnol Oceanogr 30: 598-606

Smith SL, Lane PVZ (1988) Grazing of the spring diatom bloom in the New York bight by the calanoid copepods Calanus finmarchicus, Metridia lucens and Centropages typicus. Cont Shelf Res 8:485-509

Stoecker DK, Gifford DJ, Putt M (1994) Preservation of marine planktonic ciliates: losses and cell shrinkage during fixation. Mar Ecol Prog Ser 110;293-299

Sverdrup HU (1953) On conditions for the vernal blooming of phytoplankton. J Cons Explor Mer 18:287-295

Tande KS (1982) Ecological investigations on the zooplankton community of Balsfjorden, Northern Norway: generation cycles, and variations in body weight and body content of carbon and nitrogen related to overwintering and reproduction in the copepod Calanus finmarchicus (Gunnerus).

Editorial responsibility: Otto Kinne (Editor),

Oldendort/uhe, Germany
J Exp Mar Biol Ecol 62:129-142

Tande KS, Bâmstedt U (1985) Grazing rates of the copepods Calanus glacialis and $C$. finmarchicus in arctic waters of the Barents Sea. Mar Biol 87:251-258

Tiselius P (1988) Effects of diurnal feeding rhythms, species composition and vertical migration on the grazing impact of calanoid copepods in the Skagerrak and Kattegat. Ophelia 28:215-230

Tiselius P (1989) Contribution of aloricate ciliates to the diet of Acartia clausi and Centropages hamatus in coastal waters. Mar Ecol Prog Ser 56:49-56

Tiselius P, Jonsson PR, Kaartvedt S, Olsen EM, Jorstad T (1997) Effects of copepod foraging behavior on predation risk: an experimental study of the predatory copepod Parauchaeta norvegica feeding on Acartia clausi and Acartia tonsa (copepoda). Limnol Oceanogr 42:164-170

Weeks A, Conte MH, Harris RP, Bedo A, Bellan I, Burkill PH, Edwards ES, Harbour DS, Kennedy H, Llewellyn C, Mantoura RFC, Morales CE, Pomroy AJ, Turley CM (1993) The physical and chemical environment and changes in community structure associated with bloom evolution: the Joint Global Flux Study North Atlantic Bloom Experiment. Deep-Sea Res II 40:347-368

Wiborg KF (1978) Variations in zooplankton volumes at the permanent oceanographic stations along the Norwegian coast and at weathership station M(lke) in the Norwegian sea during the years 1949-72. Fiskeridir Skr Ser Havunders 16(12):465-487

Williams R, Wallace MA (1975) Sampling at ocean weather station India $\left(59^{\circ} 00^{\prime} \mathrm{N} 19^{\circ} 00^{\prime} \mathrm{W}\right)$ in 1975. Ann Biol 32: $62-64$

Submitted: January 19, 1998; Accepted: July 9, 1998

Proofs received from author(s): October 5, 1998 